\title{
AOR
}

Selected Papers of \#AoIR2020:

The $21^{\text {st }}$ Annual Conference of the

Association of Internet Researchers

Virtual Event / 27-31 October 2020

\section{AUTOMOBILE PLATFORM CAPITALISM: A VEHICULAR HISTORY OF THE DIGITAL ECONOMY}

\author{
Marc Steinberg \\ Concordia University
}

\section{Extended Abstract:}

This paper takes up a variant on the meaning of the term platform - the base structure of an automobile - to explore the discursive and labour origins of what we now call platform capitalism. The argument made in this paper is that while Nick Snricek (2016) mentions Toyotism in passing in his Platform Capitalism, there is a much more profound relationship between Toyota - and Japanese "lean manufacture" or just-in-time automobile production in general - and the platform economy than has previously been appreciated. Based on extensive historical research on the automobile industry discussions in North America and Japan, and the platform managerial literature that emerged from it, this paper will offer an alternate genealogy of platform capitalism and the managerial theory that buttresses it, with the aim to ultimately offering a distinct mode of analysis of both platform theory and platform capitalism.

The analysis in this paper takes as its starting point the importance of offering a genealogy of the mediation style digital platform theory that both celebratory (Parker, Van Alstyne, and Choudary 2016; Evans and Schmalensee 2016) and critical (Nieborg and Poell 2018; Steinberg 2019) works on the topic foreground in their accounts of platform capitalism. This includes first and foremost its close connections to Japanese and American managerial theorizations of automobile manufacture that, as this paper will show, is the starting point for theories of platform capitalism. Subsequently, this paper will trace some of the continuities in precarious labour practices and data collection that connect the Toyota Production System (Ohno 1988) to contemporary platform capitalism. While the aim is not to discount important transformations that have taken place between the 1970s and 2010s, this paper will suggest that attention to the platform discourse and practice of the automobile industry draws attention to the continuities at play between the Toyotist moment and contemporary platform capitalism Suggested Citation (APA): Steinberg, M. (2020, October). Automobile Platform Capitalism: A Vehicular History of the Digital Economy. Paper presented at AolR 2020: The $21^{\text {th }}$ Annual Conference of the Association of Internet Researchers. Virtual Event: AolR. Retrieved from http://spir.aoir.org. 
- including the precarious labour practices (Scholtz 2017) that characterize the gig economy. This allows us to paint a more accurate picture of the history of the contemporary platform economy.

Offering a genealogy of platform thinking around the automobile and then the internet, this paper traces an unlikely link between managerial theory around automobile manufacture from the 1980s, to the development of platform theory in the 1990s in Japan, to internet-based contemporary platforms. The main trait of mainstream managerial platform theory today - thinking that informs Silicon Valley practices and platform building the world over - is an understanding of the platform as a mediator of transactions. This is the transactional theory of platforms commonly attributed to organizational economists Rochet and Tirole (2003) in France, and Parker and Van Alstyne (2005) in the US. This theory has parallels with Annabelle Gawer and Michael Cusumano's (2002) book Platform Leadership.

Significantly, Cusumano gets his start leading the analysis of the Japanese auto sector and its industrial practices under the auspices of the MIT's International Motor Vehicle Program, during the 1980s. It is from here that some of the earliest theorization of the platform economy emerges - albeit through analyses of car manufacture (Cusumano 1985). The use of the term platform in the automobile industries is one of the first sites where we see an overt combination of hardware production and business strategy. This usage implies a certain transformation of assembly lines with an eye to building multiple models of cars from a single "base," or standard, and coincides with the optimization of automobile production under the Toyotist system of manufacture that shook up the global automobile industry during the 1970 s and 80 s. Platform here denotes a standardization of the base element of the car - the ground, or foundation - upon which different bodies could be placed. This paper will furthermore argue that the missing link between automobile platform theory and the theory of the platform as mediation device is to be found in a series of articles that come out of managerial theory in the 1990s Japan. From 1993-94 when several essays and an edited collection on "Platform Business" was first published, Japanese scholars (Kokuryō 1994; Imai 1994) develop an analysis of the function of platforms (particularly Internet-mediated auctions) as intermediaries or transactional sites, in the context of analyses of the impacts of the internet on company organization - thereby anticipating a later move by North American economists (Parker and Van Alstyne 2005).

In part economic history of the Internet, in part history of platform capitalism, this paper offers a different view onto the platform economy, through attention to the models of the platform at play both in the automobile industry and subsequently in the information technology industry. It further offers a historical typology of platforms models that emerge from the automobile industry and are still dominant in managerial and critical platform studies today. The automobile today once again figures as the site for innovations in the current digital economy as both a site for autonomous driving and for ride-hailing services (Chen \& Qiu 2019). This paper presents an opportunity to reconsider the legacy of the platform concept in the automobile industry, and its hitherto unexplored impacts on the economic models of the internet that inform the platform economy in general. 


\section{References}

Chen, J. Y., \& Qiu, J. L. (2019). Digital utility: Datafication, regulation, labor, and DiDi's platformization of urban transport in China. Chinese Journal of Communication, 1-16.

Cusumano, Michael A. The Japanese automobile industry: Technology and management at Nissan and Toyota. Cambridge: Harvard, 1985.

Evans, David S. and Richard Schmalensee. Matchmakers: The New Economics of Multsided Platforms. Boston: Harvard Business Review Press, 2016.

Gregg, Melissa. Counterproductive: Time management in the knowledge economy. Duke University Press, 2018.

Imai Kenichi. "Hajime ni" [Preface]. In "Platform Business," edited by Imai Kenichi and Kokuryō Jirō, InfoCom REVIEW (Winter 1994).

Kokuryō Jirō. Ōpun nettowāku keiei: kigyō senryaku no shinchōryū [Open Network Management: New Trends in Business Strategy]. Tokyo: Nihon keizai shinbunsha, 1995.

-----. "Purattofōmu bijinesu no torihiki chūkai kinō to 'ōpun-kei keiei'” [Platform Businesses as Facilitators of Transactions and their Role in Encouraging 'Open' Management]. In "Platform Business," edited by Imai Kenichi and Kokuryō Jirō, InfoCom REVIEW (Winter 1994).

Nieborg, David B. and Thomas B. Poell. "The platformization of cultural production: Theorizing the contingent cultural commodity." In new media \& society (2018): 1-18.

Nobeoka Kentarō. Muruchi purojekuto senryaku: Posuto riin no seihin kaihatsu manejimento [Multi-Project Strategies: The Post-Lean Management of Product Development]. Tokyo: Yuhikaku, 1996.

Ohno, T. (1988). Toyota production system: beyond large-scale production. Portland: Productivity Press.

------, and Marshall Van Alstyne. "Two-Sided Network Effects: A Theory of Information Product Design." Management Science 51, no. 10 (Oct. 2005): 1494-1504.

Parker, Geoffrey, Marshall Van Alstyne, and Sangeet P. Choudary. Platform Revolution: How Networked Markets are Transforming the Economy and How to Make Them Work for You. New York: W. W. Norton \& Company, 2016.

Rochet, Jean-Charles, and Jean Tirole. "Platform Competition in Two Sided Markets." Journal of the European Economic Association 1, no. 4 (June 2003): 990 -1029. 
Scholz, Trebor. Uberworked and underpaid: How workers are disrupting the digital economy. John Wiley \& Sons, 2017.

Srnicek, Nick. Platform Capitalism. Malden: Polity Press, 2016.

Steinberg, Marc. The Platform Economy: How Japan Transformed the Consumer Internet. Minneapolis: University of Minnesota Press, 2019. 